\title{
There's Chemistry Between Us: European Transition to Transition
}

\author{
Anže Dolinar
}

\section{European Transition to Transition}

Transition state of a chemical reaction is a particular configuration along the reaction coordinate. In chemistry this state is characterized by a specific property of irreversibility and corresponds to the highest energy level along a certain reaction coordinate. One of the qualities of transition state is its indetermination. In other words, we do not know what really goes on in that state, all we have are approximations.

What concerns me here is the transition state of nation states as a specific configuration corresponding to this chemical analogy. If this analogy holds true two equally important consequences will inevitably follow. Firstly, when a nation state enters the period of transition it is not able to turn the clock. The old becomes old and remains only as a specific residue subjected to political conflict and struggle. Secondly, the state of transition will hold a specific quality of "high energy level". This means that transition itself will for a brief period of time hold the potential which will surpass its previous as its future state. At last, a complete description of a transition state will not be possible, only its approximations.

I will back my attempt at this subject by certain insights provided by Etienne Balibar, concerning the phenomena of borders and frontiers. As the starting point of this inquiry and its referential line of thought I pose the example of Slovenian transition, namely the period betwixt Slovenian independence in 91' and Slovenian entry into the European Union in 2004.

\section{Approximation No.1: Creation of civil society in Slovenia}

\section{1}

As far as the gradual collapse of Yugoslavia is concerned, there is a specific momentum I'd like to reconsider. It is the so called JBTZ affair. In the year of 1988 a socially critical magazine Mladina published a series of articles criticizing federal defense minister Branko Mamula. At the end of May of that year three Mladina journalists and a non-commissioned officer were charged with disclosure of military secrets. When all four were found guilty a crowd of 50000 surrounded the courthouse in Ljubljana and prevented the military from taking them immediately to prison. Even though the historical implications of that day necessarily bear their weight my intention is to point out the rise of a large civil society in Slovenia. During the 80's Slovenia has witnessed a rise of critical art which culminated in the band Laibach and so called Neue Slovenische Kunst (New Slovene Art). Nevertheless the JBTZ affair and the rise of civil society is what interest me here.

The reason for my interest is an article in Mladina dating in time before the JBTZ affair. The article was written by- at that time a Mladina writer - Slavoj Žižek and is titled: Paris 86: Demand, not a request. In it Žižek proposes sort of an update on Althusser's notorious theory of Ideological apparatuses of the state (from now on IAS). This update suggests that what is missing in Althusser's theory is the inclusion of civil society itself under the IAS. As Žižek 
notices the thesis itself seems contradictory at first, but is it really? Contradiction itself is the core of the problem here - as Žižek continues. Civil society is the suppressed missing part of IAS. The IAS could never have worked without this suppressed component. It is clear that the thesis itself in some way resembles the one Etienne Balibar suggested for literature and in overall account corresponds to theories of bio politics and society of control. To stick with Balibar, literary work is where ideological contradictions are produced. These are the specific contradictions that cannot be resolved in the sphere of IAS. To return to civil society - in agreeance with our thesis -we must now hold true that there is something inherently ideological and unconscious in it. The suggestion is that the very core of our western ideal holds an ideological character.

\section{2}

To return to our starting position and the events that took place during the JBTZ affair we must now presuppose the ideological character of the very same civil society that gradually led to Slovenia's independence. An idea which some might call an insane blasphemy but still one worth reconsidering. For if we are able to pinpoint this subversive ideological character we can uphold the thesis and at the same time learn something new about the nature of civil society itself. Ironically such a task does not seem to be extremely difficult. Twenty three years have past since the JBTZ affair and our political and cultural space still seems to be filled up with the very same people that surrounded the courthouse that day.

The momentum that created this large civil society could be considered as one corresponding to a "high energy level". The rise of civil society was flamed by a nation-wide anti Yugoslav and pro democratic emotions. Slovenes were - unlike people in other republics - not so much filled with nationalist emotions. Slovenia was in fact ethnically the most coherent society and that would only change in a small degree after the oil crisis in 73 ' and the arrival of Yugoslav labor force to Slovenia. Nevertheless the ideas behind this civil society were pretty much clear. The problem that arose and remained is as follows. As one part of civil society would focus its struggle against everything connected with Yugoslavia and socialism another one would in light of changing geopolitical circumstances and the rise of nationalism in republics of Croatia and Serbia prefer to direct its criticism towards the political situation in Yugoslavia at that time. In fact as we know a proposition was made to reform Yugoslavia in a loose federation but was quashed by Milošević. In a mass movement of cultural figures, intellectuals, media and others such polarization of civil society might have been blurred but the difference was nevertheless there.

\section{3}

The entry of Slovenia in the European Union in 2004 has for some people signified the end of the transition period but how could that be? We have seen that a momentum of a democratic civil movement has during the years fragmented, but still held to its ideological character of this mentioned différance. Ideological components of this civil society can be witnessed everywhere, from every day politics to main media figures, art and so on. The fight against the Yugoslavian central authority has left us with dangerous wounds. As the country is currently in an obvious political crisis some have called out to new generations to step up, but can they really? Gabriel Almond and Sidney Verba [1] seem to think so as they find the consolidation of civic culture as one that is finalized by the exchange of generations. I would however object as ideology - as we know - has no history and it seems that it will take something quite different to escape the transitional bubble. Irreversibility thus strikes us as a unique property of the future and not so much of the past. As Balibar noted in We, the people of Europe, the irreversibility of the historical change is very much problematic.

\section{Approximation No. 2: Borders of Europe}

\section{1}

As it is obviously still quite "dangerous" to explicitly refer to the above events let me at this point simply take that as a confirmation of the point I was trying to make. I am inclined to interpret the transition state as the interval between the years of 91' and 04'. During this interval there have undoubtedly been moments worth mentioning especially those where the line between politics and economy was blurred. For one, there was a privatization cycle during which state owned property was sold or distributed to private owners.

What seems important regarding a series of scandals regarding privatization is the loss of faith in state 
institutions. Backed by the work of Claus Offe 2 we can say that the economic turbulences - that inevitably encompass democratic consolidation of a post authoritarian system - can only result in a stable society if a series of social fuses are established along the way. We are basically saying that along the transformation to capitalism and free market economics there must be a process of democratization and at this precise point things seem to have gone wrong. The idea that capitalism no longer requires democracy as its historical partner is of course not new. Nevertheless the situation in a state of transition is somewhat unique.

\section{2}

I will attempt to approach this subject trough already mentioned insights of Etienne Balibar. Although theories of transition mostly address the subjects of democracy and capitalism - that is political and economical liberalizationmy main focus here will be addressing the phenomena of borders. Borders are the everlasting element of European society and culture. We could even stress that it was Europe itself that exported the phenomena of border into the world during colonization period. Furthermore borders seem to be the underlying element of democracy and capitalism. To successfully complete a transition, a country must enter the European Union - that is the silent imperative and consensus. However we can clearly see that newcomers do not have the same status as the old member states. Two-speed or multi-speed Europe is not simply an isolated incident of slow service in a restaurant but a real problem with no obvious or simple solution.

The problem here in my opinion, following the insights of Balibar, is that borders are falling in strictly economic terms. As every activity now assumes the form of commodity exchange in a "free" environment all that is left are forms of internal exclusion. To stress the idea further - borders themselves are the point where democracy stops and free market economics begins. Here political participation becomes the rule of the police state. Recent deportations of Roma people from France to Romania (Another EU state) are a good example of that ( The fact that Roma people were paid to leave does not change the motive and the attitude behind this act). Borders are not democraticthey do not apply to goods and people in the same manner. Which is more, borders are multiplying and fluctuating. The fact that state borders are falling inside the European Union simply means that new borders are being formed on other levels, assuming different functions.

Transition states or those which have supposedly ended the transition period are the states that are predominantly affected by these phenomena. Third world begins in the suburbs as J.P Sartre once wrote and today the suburbs of Europe are the new states, transition states.

\section{Approximation No. 3: Heideggerian slip}

\section{1}

One of the qualities of a transition state of a chemical reaction is the fact that we know exactly what the product will look like but we still cannot determine what exactly goes on with colliding molecules during this state. Thus we can apply such a suggestion to a nation state transition as well. Specific actors and circumstances assure us that not a single transition is similar to another. There can of course be and in all fairness are theories that attempt to merge social, cultural, political and economical predispositions that are required for a successful transition.

Nevertheless the point I am trying to make is that European Union itself is in a state of constant transition. Not only are new countries joining EU but also its role as a subject of global politics is shifting and changing rapidly. As the demand for a unified foreign policy increases, we more and more witness the failure of EU countries to construct one. Recent events in Libya have proven that point as has the failed project of a joint EU constitution. It seems than that it is not exactly clear what it means to live in Europe or even to build one.

\section{2}

In his 1951 essay Building, Dwelling, Thinking Martin Heidegger sets out to clarify the relationship between these phenomena. One of his insights is that building something in its essence already presupposes living in this something. His further clarification shows an etymological relationship between terms "bauen" and "bin". Building is a succession as we first build, than nurture and finally set something on its place. Furthermore the word "Wohnen" or to dwell would mean to stay somewhere and be at peace. To dwell somewhere gives us a chance to open new spaces and move between them. It is building that sets these dwelling places and synchronizes different spaces. 
As abstract as this may sound it is exactly the way in which we should approach questions of European identity and integrity. Historical formation of European space is triggered by the rise of sciences. What is called arts in the Anglo - Saxon world is what we know as "humanitas". Humanitas is based in historical consciousness, its inner strength is called tolerance and what is known as an experiment in natural sciences is called discipline in arts. Humanitas in its essence is thus not a social science it's much more- as Heidegger noted-interconnected with the Greek term "paidea" which is usually translated as education but more than that signifies a sort of citizen virtue. The term "paidea" has been reconsidered by many philosophers since Plato has placed it in his Laws. Hannah Arendt has stressed it in great detail especially in relation to authority. As this is no place to address such difficult topics let me simply point out that humanitas is one of the pillars of European heritage. The difference between an authoritarian and a dictatorial system can be traced through the prism of "paidea". It is for this reason why so many philosophers are still dealing with the phenomenon of Nazism and holocaust. Events in Srebrenica, the ICC, the role of UN and Europe are a recent reminder that a phenomenon of violence cannot be taken lightly or be simplified by persecution of single individuals.

To put things into context we should say that in the legacy of European arts lies a key to transpose new borders that are emerging inside Europe. It is dictatorship we fear most and in our fear we cripple ourselves. Fear can be only surpassed via understanding

\title{
4. Conclusion
}

Borders themselves are what we should thus reconsider while trying to build a European identity. Europe should be more than a simple mediator between a powerful West and "savage" East. European identity is a global one and the ability of Europe to democratize the borders established internally should have global effects. Far more than such an attempt should be limited to the political apparatus it is imperative to find solutions inside emerging civil societies such as those we are today witnessing in Spain, we have witnesses yesterday in Greece and will tomorrow in some other EU country. The destruction of an ideological moment of such movements should be carried out as a destruction of borders and a brake with the past. Thus I find the slogan of Bologna Burns movement: "No border, no nation, free education" as one that should symbolize European identity far more than any EU institution.

At the same time we the people of Europe can look outside for inspiration. The events that took place in Chiapas in 94' and the striking writings of Subcomandante Marcos are a constant reminder that change is possible. The heritage of European philosophy is the heritage of the world and as such it should be a corner stone of future projects and actions. Already the protesting masses throughout Europe have proven that they have much more in common than the bureaucrats they are paying to represent them. A global multitude of oppressed, exploited and marginalized people is forming and this time it's their words not guns that will count.

\section{Endnotes}

\author{
1. In Merkel,1996
}

2. Offe 1994 - in Merkel

\section{References}

Althusser, Louis. 1969. Ideology and Ideological State Apparatuses. In: Lenin and Philosophy and other essays. New York and London: Monthly Review Press
Balibar, Étienne. 2004. We, the People of Europe?. Oxford: Princeton University Press 
Balibar, Étienne, and Pierre Macherey. 1981 "On Literature as an Ideological Form." Untying the Text: A Post-Structuralist Reader. Ed. Robert Young. Boston and London: Routledge and Kegan Paul

Bennett, Christopher. 1998. Yugoslavia’s bloody collapse: Causes, course and consequences. London: Hurst\&Company

Heidegger, Martin. 1975. Building, Dwelling, Thinking. In: Poetry, Language, Thought. New York, Hagerstown, San Francisco, London: Harper Colophone Books
Merkel, Wolfgang. 1996. Politische Theorien in der Ära der Transformation. Opladen: Westdeutscher Verlag

Žižek, Slavoj. 1989. Druga smrt Josipa Broza Tita. Ljubljana: Državna založba Slovenije 
